\title{
Medical Undergraduate Students Opinion on Use of Visual Arts (Skit) in Teaching-Learning Bioethics: a Questionnaire Based Study
}

\author{
Manjeshwar Shrinath Baliga, Princy Louis Palatty, Ovine D’Souza, Taresh Shekar Naik, \\ Mohammed Adnan, Rekha Boloor, Arnadi Ramachandrayya Shivashankara.
}

UNESCO Bioethics South India Unit at Father Muller Medical College, Mangalore.

Corresponding Author : Dr Manjeshwar Shrinath Baliga, UNESCO Bioethics, South India Unit at Father Muller Medical College, Father Muller Road, Mangalore, Karnataka, India 575002

E-mail - msbaliga@gmail.com

\begin{abstract}
Teaching bioethics to medical undergraduates who have a very rigorous academic program is an arduous task. In our ongoing endeavors of innovative way of teaching Bioethics we planned to understand the opinion of students who were taught bioethics (by conventional class room teacher guided classes, debates, movies, visual arts and bed side teachings) on their choice of teaching the subject and compared it with age matched student cohorts (who were not taught bioethics). The willing students were provided with a structured questionnaire and requested to answer their choices. The questionnaire consisted of demographic and subject details. The results from this study indicated that visual arts could be an effective addendum to conventional teaching method in bioethics and needs to be incorporated.
\end{abstract}

Key words: Bioethics teaching, visual arts, skits

\section{INTRODUCTION}

Globally the lack of inculcating and training in Bioethics is being attributed for the drastic deterioration of the doctor-patient relationship and this has lead to the general public notion that health care has become materialistic [1]. To substantiate this studies have also shown that lack of proper study of ethics in medical colleges, was one of the causes for the drastic deterioration of the doctor-patient relationship. Since this observation, at a global level, bioethics training has been slowly growing and emphasis is placed on sensitizing the healthcare students, professionals and teachers to the cardinal aspects [1].

In the current context, medical education is a highly rigorous and tightly packed program and teaching of medical ethics is neglected. Additionally, unlike core medical subjects, teaching bioethics involves influencing a person's view point, to an extent where it can motivate a positive action in a real-life ethical situation [1]. The problem is compounded when we consider the fact that in addition to inculcation of the human and medical ethics, the mentor should also foster critical thinking and creative brainstorming when dealing with controversial topics. In lieu of these observations, educationists have now been proposing adoption of innovative teaching methods and skits and drama are being considered ideal [2-4]. 
The UNESCO Bioethics South India Unit at Father Muller Medical College, Mangalore India has been a centre working on teaching and inculcating medical ethics in the undergraduate heath care students. The unit which was established in August 2012 has been adopting innovative problem-based teaching methods to sensitize healthcare students to various ethical dilemmas. The principal objective in this endeavor has been to create awareness in young minds with innovative teaching techniques and without intensifying the already voluminous academic curriculum. Towards this aim, the unit has also adopted debates, movies, skits, drama and bed side teaching to educate undergraduate students on various complicated aspects in Bioethics [5]. The present study was conducted to ascertain the effectiveness of skit in teaching bioethics between students who were exposed to this teaching module (at Father Muller Medical College) with age matched medical students of other medical colleges where Bioethics was not taught.

\section{METHODOLOGY}

This is a single centre study and was conducted under the aegis of the UNESCO Bioethics South India Unit at Father Muller Medical College, Mangalore, India in the month of January 2016. The study was approved by the Institutional Ethics committee. The questionnaire was designed by the investigators and was developed with the help of medical educationists, bioethicists and researchers. Emphasis was given for clarity and comprehension by the students. The questionnaire was pilot tested on 10 students of. The respondents of the pilot cohort rated the initial questionnaire for clarity, degree of comprehension and content validity. Emphasis was also placed to have a small questionnaire to enhance maximal participation of the volunteers.

The final questionnaire consisted of two sections, the demographic and subject specific questions and filling it took a maximum of 5 minutes. For the study purposive sampling was adopted and the inclusion criteria for 1) the study population was students who had attended classes based teaching programs and were exposed to skit programs, debate and movies addressing bioethical issues. The control cohort consisted of students not associated with any of the teaching or academic programs conducted by UNESCO Bioethics and were students who had come to Father Muller Medical College for academic programs/events. The students were explained the objective of the study and also that their participation was completely anonymous and voluntary and to deposit the filled questionnaire in the collection box. Written consent was obtained on separate sheet from all the willing participants before the administration of the questionnaire and their anonymity was maintained.

\section{Statistical analysis}

Data was entered in Microsoft Excel ${ }^{\circledR}$ and analyzed on the online based Vassar Stats statistical program. All quantitative variables are illustrated through mean and standard deviation and the $t$ test was applied. The data from the questionnaire were entered in Microsoft Excel $^{\circledR}$ and analyzed using the Chi Square test. A p value of $<0.05$ was considered significant.

\section{RESULTS}

The demographic details suggest that most of the volunteers were female, $2^{\text {nd }}$ year medical students and from city domicile $(\mathrm{p}<0.025)$ (Table 1$)$. In our study it was observed that most of the students in both cohorts did not watch movies that address medical ethics and also that many of them did not participate in skit or drama (Table 2). The results also indicated that the students who were taught bioethics attended more programs $(p<0.00003)$, read books $(p<0.00001)$ and agreed skit was a useful method in teaching bioethics $(p=0.001)$ (Table 2). A greater percentage of students $(60 \%)$ who were not taught Bioethics said strongly that skits were useful in the teaching of Bioethics - kindly comment. The most significant observation of this study was students who were taught bioethics expressed that patient/family centered bed side teaching was the most effective way of teaching bioethics $(p<0.001)$ while the students who were not taught 
bioethics said the conventional class room lecture based to be the most preferred $(p=0.044)$ (Table 3).

Table 1 - Demographic details of the participants

\begin{tabular}{|c|c|c|c|c|}
\hline & $\begin{array}{l}\text { Response } \\
\text { Options }\end{array}$ & $\begin{array}{c}\text { Studied Bioethics } \\
\text { (62) }\end{array}$ & $\begin{array}{l}\text { Did not study } \\
\text { Bioethics (70) }\end{array}$ & \\
\hline \multirow{2}{*}{ Gender } & Male & $22(35.5)$ & $18(25.7)$ & \multirow{2}{*}{$\begin{array}{l}X^{2}=1.48 \\
\mathrm{P}=0.22\end{array}$} \\
\hline & Female & $40(64.5)$ & $52(74.3)$ & \\
\hline \multirow[t]{4}{*}{ Year } & I year & 4 & 6 & \multirow{4}{*}{$\begin{array}{l}X^{2}=5.06 \\
P=0.16\end{array}$} \\
\hline & II year & 42 & 34 & \\
\hline & III year & 10 & 18 & \\
\hline & Final year/intern & 6 & 12 & \\
\hline \multirow[t]{3}{*}{ Domicile } & Rural & $16(25.8)$ & $6(8.6)$ & \multirow{3}{*}{$\begin{array}{c}X^{2}=7.36 \\
\mathrm{P}=0.025 \\
\text { Significant }\end{array}$} \\
\hline & Town & $8(12.9)$ & $14(20)$ & \\
\hline & City & $38(61.3)$ & $50(71.4)$ & \\
\hline
\end{tabular}

All statistics done using the Chi square test ( $p<0.05$ significant)

Table 2 - Response of students to students on various aspects of Bioethics teaching and skit in particular

\begin{tabular}{|c|c|c|c|c|}
\hline & $\begin{array}{c}\text { Response } \\
\text { Options }\end{array}$ & $\begin{array}{c}\text { Studied } \\
\text { Bioethics (62) }\end{array}$ & $\begin{array}{l}\text { Did not study } \\
\text { Bioethics (70) }\end{array}$ & \\
\hline \multirow{2}{*}{$\begin{array}{l}\text { Have you watched movies } \\
\text { that address issues in } \\
\text { medical ethics? }\end{array}$} & Yes & $10(16.1)$ & $14(20)$ & \multirow{2}{*}{$\begin{array}{l}X^{2}=0.33 \\
P=0.56\end{array}$} \\
\hline & No & $52(83.9)$ & $56(80)$ & \\
\hline \multirow{2}{*}{$\begin{array}{c}\text { Do you read books in } \\
\text { ethics? }\end{array}$} & Yes & $28(45.2)$ & $4(5.72)$ & \multirow{2}{*}{$\begin{array}{c}X^{2}=27.85 \\
\mathrm{P}=0.00001 \\
\text { Significant }\end{array}$} \\
\hline & No & $34(54.8)$ & $66(94.28)$ & \\
\hline \multirow{2}{*}{$\begin{array}{l}\text { Have you attended } \\
\text { programs in ethics? }\end{array}$} & Yes & $26(58.1)$ & $22(31.4)$ & \multirow{2}{*}{$\begin{array}{c}X^{2}=17.48 \\
\mathrm{P}=0.00003 \\
\text { Significant }\end{array}$} \\
\hline & No & $26(41.9)$ & $58(68.6)$ & \\
\hline \multirow{2}{*}{$\begin{array}{l}\text { Participated in ethics skit } \\
\text { programs as actors? }\end{array}$} & Yes & $8(12.9)$ & $10(14.3)$ & \multirow{2}{*}{$\begin{aligned} X^{2} & =0.817 \\
\mathrm{P} & =0.057\end{aligned}$} \\
\hline & No & $54(87.1)$ & $60(85.7)$ & \\
\hline \multirow{4}{*}{$\begin{array}{c}\text { Do you think skits are } \\
\text { useful in teaching } \\
\text { Bioethics? }\end{array}$} & Strongly yes & $18(29)$ & $42(60)$ & \multirow{4}{*}{$\begin{array}{c}X^{2}=12.92 \\
\mathrm{P}=0.0001 \\
\text { Significant }\end{array}$} \\
\hline & Yes & $42(67.7)$ & $26(37.1)$ & \\
\hline & No & $2(3.2)$ & $2(2.9)$ & \\
\hline & Strongly No & $0(0)$ & $0(0)$ & \\
\hline
\end{tabular}

All statistics done using the Chi square test $(\mathrm{p}<0.05$ significant)

\section{DISCUSSION}

Since antiquity, drama has been recognized as an important model of learning and is also recognized to be a basic activity for learning [4]. In medical education especially in community medicine and public heath courses, visual arts like drama plays an integral part in educating the general public on the various health and social problems. In addition, skits and, the street plays that explore issues, events and connect with social cause are a useful educative medium [5]. Drama also encourages people to empathize themselves with an enacted character and this 
feature is of immense educational value [5]. To further substantiate this, a report published by State of the Field Committee [4] confirm that increasing numbers of healthcare professionals are working with arts professionals in both healthcare and community settings and that arts is emerging as an important and integral component of healthcare teaching and as an entertainment coefficient to mitigate the stress. In lieu of all these the investigators believed that drama can be useful for learning Bioethics curriculum and conducted this study [3].

Table 3 - Rating of students for the best method of teaching bioethics for undergraduate Medical students

\begin{tabular}{|c|c|c|c|c|c|c|c|c|}
\hline \multirow[t]{2}{*}{$\begin{array}{l}\text { Rating of } \\
\text { students }\end{array}$} & \multicolumn{2}{|c|}{$\begin{array}{l}\text { Conventional class } \\
\text { room teaching }\end{array}$} & \multicolumn{2}{|c|}{$\begin{array}{l}\text { Movies and } \\
\text { documentary }\end{array}$} & \multicolumn{2}{|c|}{$\begin{array}{l}\text { Visual arts (Skits, } \\
\text { mime \& drama) }\end{array}$} & \multicolumn{2}{|c|}{$\begin{array}{l}\text { Bedside \& patient } \\
\text { interaction }\end{array}$} \\
\hline & $\begin{array}{l}\text { Studied } \\
\text { Bioethics }\end{array}$ & $\begin{array}{l}\text { Did not } \\
\text { study } \\
\text { Bioethics }\end{array}$ & $\begin{array}{l}\text { Studied } \\
\text { Bioethics }\end{array}$ & $\begin{array}{c}\text { Did not } \\
\text { study } \\
\text { Bioethics }\end{array}$ & $\begin{array}{l}\text { Studied } \\
\text { Bioethics }\end{array}$ & $\begin{array}{c}\text { Did not } \\
\text { study } \\
\text { Bioethics }\end{array}$ & $\begin{array}{l}\text { Studied } \\
\text { Bioethics }\end{array}$ & $\begin{array}{l}\text { Did not } \\
\text { study } \\
\text { Bioethics }\end{array}$ \\
\hline $1^{\text {st }}$ choice & $14(22.6)$ & $22(31.4)$ & $18(29.0)$ & $12(17.1)$ & $12(19.4)$ & $12(17.1)$ & $26(41.9)$ & $16(22.9)$ \\
\hline $2^{\text {nd }}$ choice & $4(6.50)$ & $18(25.7)$ & $12(19.4)$ & $10(14.3)$ & $22(35.5)$ & $20(28.6)$ & $12(19.4)$ & $10(14.3)$ \\
\hline $3^{\text {rd }}$ choice & $10(16.10)$ & $2(2.90)$ & $16(25.8)$ & $30(42.9)$ & $22(35.5)$ & $24(34.3)$ & $14(22.6)$ & $24(34.3)$ \\
\hline $4^{\text {th }}$ choice & $34(54.8)$ & $28(40.0)$ & $16(25.8)$ & $18(25.7)$ & $6(09.7)$ & $14(20)$ & $10(16.1)$ & $20(28.6)$ \\
\hline$X^{2}$ & \multicolumn{2}{|c|}{16.17} & \multicolumn{2}{|c|}{5.25} & \multicolumn{2}{|c|}{2.91} & \multicolumn{2}{|c|}{8.07} \\
\hline Pvalue & \multicolumn{2}{|c|}{0.001 Significant } & \multicolumn{2}{|c|}{0.15} & \multicolumn{2}{|c|}{0.40} & \multicolumn{2}{|c|}{ 0.044 Significant } \\
\hline
\end{tabular}

All statistics done using Chi square test ( $\mathrm{p}<0.05$ significant)

In the present study we conducted a study to ascertain the effectiveness of using skits as a teaching medium bioethics with students being taught and compared it with age matched cohorts that were not taught Bioethics. The results showed that although skit was appreciated by all the participants the students who were not taught bioethics strongly agreed it to be a useful medium than the ones who were taught (Table 2). Further it was also observed that students who were taught bioethics rated bedside and patient interaction $\left(1^{\text {st }}\right)>$ movies $\left(2^{\text {nd }}\right)>$ conventional class room teaching $\left(3^{\text {rd }}\right)>$ skit and drama $\left(4^{\text {th }}\right)$; while the students who were never exposed to bioethics teaching had this rating conventional class room teaching $(1 \mathrm{st})>$ bedside and patient interaction $\left(2^{\text {nd }}\right)>$ movies $\left(3^{\text {rd }}\right)=$ skit and drama $\left(3^{\text {rd }}\right)$. These observations assume great significance from the perspective of medical education and Bioethics. The results clearly indicate that skits and drama can be a very useful medium to enthuse and teach bioethics to students who are unaware of the aspects.

\section{CONCLUSIONS}

This study investigated skit as a teaching-learning methodology, among medical students. The authors believe that attitudinal changes happen insidiously and not from a one-time stimulus but through constant prodding via factual information and reinforcement by case scenarios analysis. Visual arts like drama, plays and skits initiate an impact in the viewers and also helps ingrain various sensitive issues in the minds of the audience. With time and with careful tutelage these concepts can percolate deeply in the young minds to produce a definitive attitudinal change. In this regard skit is useful because in addition to being educative they also have an entertainment value which on its own also helps in mitigating the stress of a rigorous medical 
curriculum/profession. Further studies are being planned to investigate the usefulness of skit in teaching complicated Bioethical issues like surrogacy, end of life issues.

\section{Acknowledgements}

- The authors are grateful to all the participating students for sharing their time to fill the questionnaire.

- We also acknowledge the significant support provided by the UNESCO Bioethics South India members of Father Muller Medical College, Mangalore, India.

\section{REFERENCES}

1. Emanuel EJ. Preserving the Physician-Patient Relationship in the Era of Managed Care. J Am Med Assoc 1995;273:323-9.

2. Edmiston B. Drama as Ethical Education. Res Drama Educn 2000;5:63-84.

3. Shapiro J and Cho B. Medical Readers' Theater: Relevance to Geriatrics Medical Education. Gerontology \& Geriatrics Education. 2011;32;350-63.

4. State of the Field Committee. (2009). State of the field report: Arts in healthcare 2009. Washington, DC: Society for the Arts in Healthcare.

5. Reed RR. The deprofessionalization of medicine: Causes, effects, and responses. J A Med Assoc. 1987; 258(22):3279-82.

6. Üstündağ T. The advantages of using drama as a method of education in elementary schools. Hacettepe Üniversitesi Eğitim Fakültesi Dergisi 1997;13:89-94.

Acknowledgements - Nil

Source of Funding - Nil

Conflict of Interest - Nil 